\title{
Degradation kinetics and assessment of the prediction equation of indigestible fraction of neutral detergent fiber from agroindustrial byproducts
}

\author{
José Gilson Louzada Regadas Filho ${ }^{1}$, Elzânia Sales Pereira ${ }^{1}$, Patrícia Guimarães Pimentel ${ }^{1}$, \\ Tadeu Silva de Oliveira ${ }^{2}$, Marcus Roberto Góes Ferreira Costa ${ }^{1}$, lana Sérvulo Gomes Maia ${ }^{1}$
}

\footnotetext{
${ }_{1}$ Departamento de Zootecnia, Universidade Federal do Ceará - UFC.

2 Departamento de Zootecnia, Universidade Federal de Viçosa - UFV.
}

\begin{abstract}
This study aimed at estimating the kinetic parameters of ruminal degradation of neutral detergent fiber from agroindustrial byproducts of cashew (pulp and cashew nut), passion fruit, melon, pineapple, West Indian cherry, grape, annatto and coconut through the gravimetric technique of nylon bag, and to evaluate the prediction equation of indigestible fraction of neutral detergent fiber suggested by the Cornell Net Carbohydrate and Protein System. Samples of feed crushed to $2 \mathrm{~mm}$ were placed in $7 \times 14 \mathrm{~cm}$ nylon bags with porosity of $50 \mu \mathrm{m}$ in a ratio of $20 \mathrm{~g} \mathrm{DM} / \mathrm{cm}^{2}$ and incubated in duplicate in the rumen of a heifer at $0,3,6,9,12,16,24,36,48,72,96$ and 144 hours. The incubation residues were analyzed for NDF content and evaluated by a non-linear logistic model. The evaluation process of predicting the indigestible fraction of NDF was carried out through adjustment of linear regression models between predicted and observed values. There was a wide variation in the degradation parameters of NDF among byproducts. The degradation rate of NDF ranged from $0.0267 \mathrm{~h}^{-1}$ to $0.0971 \mathrm{~h}^{-1}$ for grape and West Indian cherry, respectively. The potentially digestible fraction of NDF ranged from 4.17 to $90.67 \%$, respectively, for melon and coconut byproducts. The CNCPS equation was sensitive to predict the indigestible fraction of neutral detergent fiber of the byproducts. However, due to the high value of the mean squared error of prediction, such estimates are very variable; hence the most suitable would be estimation by biological methods.
\end{abstract}

Key Words: CNCPS, feed, fruit, ruminants

\section{Introduction}

The need for good quality feed with low cost for farm animals in the dry season is constant in all systems and even more accented in tropical regions of semiarid climate. In such regions, the improvement of livestock production is based on the knowledge and use of feeding strategies via native and exotic adapted forage resources and also the use of agroindustrial byproducts, which have become increasingly common as alternative feed, considering the great potential of these regions for irrigated fruit culture.

In order to obtain reliable estimates of digestive parameters of feed, it is necessary to have the knowledge of the ruminal degradation rates of the nutritional components (Detmann et al., 2009). These rates are almost unknown in byproducts from fruit culture agroindustry, which present great potential for use as livestock feed.

Furthermore, the feed evaluation systems that provide support for formulating feeds for ruminants and use mechanistic relationships to predict the availability of energy and protein from dietary components are dependent on plausible values of rates of digestion and passage of feed fractions; and fiber is the feed fraction that presents bigger variation in these parameters. These systems, like the Cornell Net Carbohydrate and Protein System (CNCPS) aim to synchronize the availability of energy and protein in the rumen, maximize microbial efficiency, feed digestion, and reduce losses resulting from ruminal fermentation (Cabral et al., 2005).

Given the above, the objective of the present study was to estimate the degradation kinetics of NDF from some agroindustrial byproducts and evaluate the prediction equation of indigestible fraction of neutral detergent fiber adopted by the Cornell Net Carbohydrate and Protein System.

\section{Material and Methods}

The agroindustrial byproducts of cashew (Anacardium occidentale), passion fruit (Passiflora eduli), melon (Cucumis melo),pineapple (Ananasco mosus L., Merr), West Indian cherry (Malpighia emarginata) and grape (Vitis vinifera L.) were collected in agroindustries of processing and production of industrial juice, mainly 
composed of seeds, peel and pulp residue. The byproduct from annatto (Bixa orellana L.) was obtained from the extraction of the bixin dye. The cashew nut was obtained in agro-processing industry, from nuts inappropriate for human consumption and residue in meal derived from its processing. The byproduct of coconut (Cocos nucifera) was collected from the endosperm processing in an industry for the production of coconut milk.

Samples derived from agroindustries of fruit juice and coconut milk were dehydrated in the natural conditions, in the sun, in cemented area and spread in layers of about 7 -cm thick, being revolved three times a day until reaching a moisture content between 13 and $16 \%$; and this management is used by cattle breeders who employ such byproducts in regions where the samples were gathered.

All the samples were sent to Laboratório de Nutrição Animal do Departamento de Zootecnia of the Universidade Federal do Ceará, then milled in Willey-type mill, equipped with sieve (1 mm diameter) and analyzed for the contents of dry matter (DM; AOAC, 1990; method number 967.03), mineral matter (MM; AOAC, 1990; method number 924.05), crude protein (CP; AOAC, 1990; method number 981.10), ether extract(EE; AOAC, 1990; method number 920.39), acid detergent fiber and lignin by sulphuric acid method (ADF and ADL; AOAC, 1990, method number 973.18). The analysis of neutral detergent fiber was performed according to Mertens (2002) with thermo-stable alpha amylase without using sodium sulfite and corrected for ash (Mertens, 2002) and protein compounds $\left(\mathrm{NDF}_{\mathrm{om} ; \mathrm{p}}\right.$ ) (Licitra et al., 1996).

Total carbohydrates were determined by the following equation TC $=100-(\% \mathrm{CP}+\% \mathrm{EE}+\% \mathrm{MM})$, (Sniffen etal., 1992). Non-fibrous carbohydrates were determined by the difference between $\mathrm{TC}$ and the $\mathrm{NDF}_{\mathrm{om} ; \mathrm{p}}$.

The kinetic parameters of ruminal degradation of NDF of the byproducts were estimated by gravimetric technique of nylon bag proposed by Ørskov \& McDonald (1979). For this purpose, a new milling of the byproducts was performed in Willey-type mill with sieve ( $2 \mathrm{~mm}$ diameter) and placed in a $20 \mathrm{~g} \mathrm{DM} / \mathrm{cm}^{2}$ ratio in nylon bags $(7 \times 14 \mathrm{~cm})$ with porosity of $50 \mu \mathrm{m}$, previously dried in forced ventilation oven $\left(65^{\circ} \mathrm{C} / 48 \mathrm{~h}\right)$ and weighed.

Byproducts' samples were incubated in duplicate in the rumen of a heifer with about $350 \mathrm{~kg}$ fed twice daily with hay Tifton- 85 and concentrated (12\% CP) based on corn and soybean meal in a forage:concentrate ratio of 70:30. Incubation times were $0,3,6,9,12,16,24,36,48,72,96$ and 144 hours. There were two incubation sets, in reverse order to allow the removal of all bags of each set together. In the first set we incubated five byproducts (cashew, passion fruit, melon, pineapple and West Indian cherry), and in the second, the four byproducts remaining (cashew nut, annatto, coconut and grape).

Immediately after being removed from ruminal environment, the bags were placed in a bucket with cold water to halt microbial activity and then rinsed under running water until it showed clear. Bags corresponding to time zero hour were washed with the others, all the bags were predried in forced ventilation oven at $65^{\circ} \mathrm{C}$ for 72 hours and then weighed. Residues were examined for DM and NDF.

NDF degradation profiles obtained by the procedure above described were kinetically interpreted by using the model proposed by Van Milgen et al. (1991):

$$
R\left(t_{i}\right)=U \times \frac{[c \times \exp (-p \times t)-p \times \exp (-c \times t)]}{(c-p)}+I
$$

where: $\mathrm{R}\left(\mathrm{t}_{\mathrm{i}}\right)=$ incubation residue $(\%)$ after a given time $\mathrm{t}$ (hours); $\mathrm{U}=$ potentially degradable fraction of NDF not available at time zero (\%NDF); I = asymptote reached by the function when $t_{i} \rightarrow \infty$, corresponds to NDF undegradable fraction $(\% \mathrm{NDF}) ; p=$ dynamic latency rate $\left(\mathrm{h}^{-1}\right)$; and $c=$ degradation rate $\left(\mathrm{h}^{-1}\right)$ of the potentially degradable fraction of carbohydrates contained in the cell wall. Nevertheless, in all byproducts assessed the $p$ parameter tended towards $c$, so it was necessary to reparametrize the model by applying L'Hôpital's rule, as follows:

Table 1 - Bromatological composition of agroindustrial byproducts

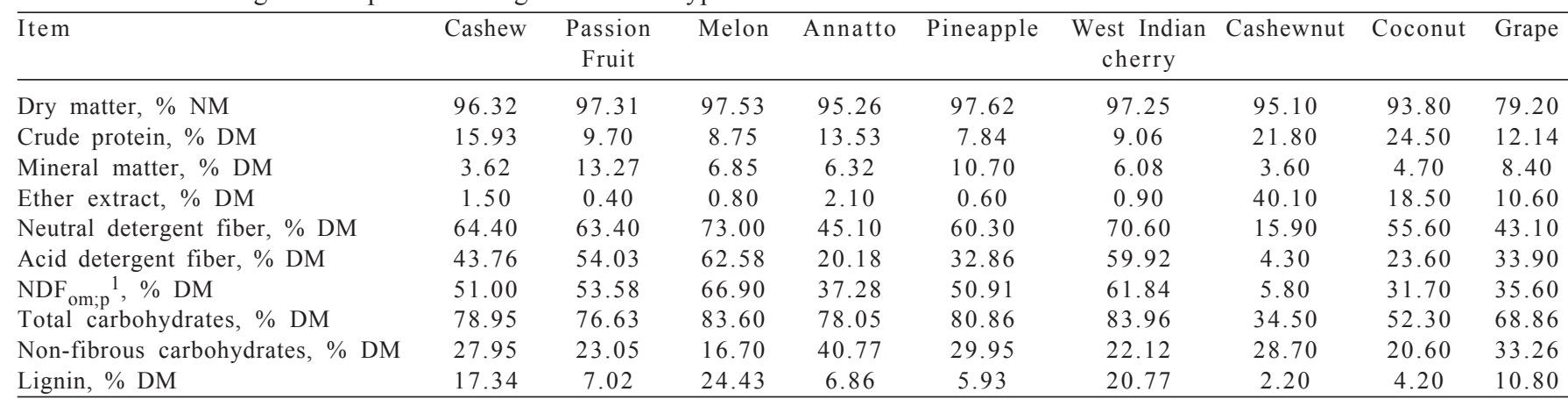

${ }^{1}$ Neutral detergent fiber corrected for ash and protein. 


$$
R\left(t_{i}\right)=U \times(1+\lambda \times t) \times \exp (-\lambda \times t)+I
$$

whose mathematical interpretation is $\lambda=c=p$ and corresponds to the degradation rate when $p$ tends to $c$. Because the parameter $\lambda$ jointly represents the rates of degradation and latency, a direct biological comparison with $c$ parameter is impossible (Costa et al., 2008). In this way, we estimated the fractional rate of degradation from $\lambda$, using the properties of the gamma-2 distribution (Ellis et al., 1994):

$c^{\prime}=0.59635 \times \lambda$

where: $c^{\prime}=$ fractional rate of degradation of potentially degradable NDF $\left(h^{-1}\right)$.

The effective ruminal degradation (ERD) was obtained according to Ørskov \& McDonald (1979):

$$
E R D=\lim _{t \rightarrow \infty} \int_{0}^{t}[f(t) \times(-d R t / d t)] d t
$$

where: $\mathrm{ERD}=$ effective ruminal degradation $(\%)$; and $f(\mathrm{t})=$ function concerning the displacement of solids in the rumen. We assumed ruminal displacement of solids of gamma-1 order (Ellis et al., 1994), according to the following equation: $f(t)=\exp (-k \times t)$

where: $\mathrm{k}$ = passage rate from rumen to lower digestive tract $\left(h^{-1}\right)$, which designated, hypothetically, the values of 0.02 and 0.05 .

Thus, we estimated the ERD from the next equation:

$$
E R D=U \times \lambda^{2} /(\lambda+k)^{2}
$$

The effect of rumen fill or rumen repletion of the potentially degradable fraction $\left(R R_{U}\right)$ and of the undegradable fraction $\left(\mathrm{RR}_{\mathrm{I}}\right)$ of NDF was determined in agreement with Waldo et al. (1972) by the expressions:

$$
\begin{aligned}
& R R_{U}=U_{p} \times\left[(2 \lambda+k) /(\lambda+k)^{2}\right] \\
& R R_{I}=I_{p} / k \\
& R R_{T}=R R_{U}+R R_{I}
\end{aligned}
$$

where: $\mathrm{RR}_{\mathrm{t}}=$ effect of total fill; $\mathrm{Up}=$ potentially degradable standardized decimal fraction $[\mathrm{Up}=\mathrm{U} /(\mathrm{U}+\mathrm{I})] ; \mathrm{Ip}=$ undegradable standardized decimal fraction $[\mathrm{Ip}=\mathrm{I} /(\mathrm{U}+\mathrm{I})]$

In order to estimate discrete latency (L), we used the assumptions from Vieira et al. (1997), so it was necessary to obtain the coordinate $\mathrm{P}\left[\mathrm{t}_{\mathrm{i}}, \mathrm{R}(\mathrm{ti})\right]$ or inflection point of the fitted curve of degradation, so that from this we can calculate the latency as:

$$
L=\frac{R(0)-R\left(t_{i}\right)}{\mu}+t_{i}
$$

where: $\mathrm{L}=$ discrete latency $(\mathrm{h}) ; \mathrm{R}(0)=$ residue of undegraded $\mathrm{NDF}$ at $\mathrm{t}=0(\%) ; \mathrm{R}\left(\mathrm{t}_{\mathrm{i}}\right)=$ residue of undegraded NDF at the inflection point of the degradation curve (\%); $\mu=$ first derivative of the fitted curve of degradation corresponding to the slope of the tangent line to inflection point or point of maximum degradation rate and $t_{i}=$ time equivalent to the inflection point of the degradation curve (h)

Values of $t_{i}$ were obtained from Van Milgen et al. (1991) and Vieira et al. (1997), according to the following equation: $t_{i}=1 / \lambda$

Assuming that the digested mass of the potentially digestible fraction is directly proportional to the microbial mass synthesized, it is possible to estimate the growth rate of microorganisms from the digestion of the substrate (Brock et al., 1994). In this way, the specific growth rate of microorganisms on the potentially degradable fraction of the byproducts was estimated by the expression (Beuvink \& Kogut, 1993):

Sgr $=\mu / U$

where: $\operatorname{Sgr}\left(\mathrm{h}^{-1}\right)$ is the specific growth rate of microorganisms on the potentially degradable fraction.

From estimates of Sgr, we obtained the efficiencies of microbial growth, in accordance with the propositions of Pirt(1965):

$1 / Y=m / S g r+1 / Y m$

where: $\mathrm{Y}=$ microbial efficiency $\left(\mathrm{g}\right.$ cells x $\mathrm{g}^{-1}$ carbohydrate degraded in rumen); $m=$ maintenance requirement of bacteria ( $\mathrm{g}$ carbohydrate $\mathrm{x}^{-1}$ cell $\mathrm{x} \mathrm{h}^{-1}$ ); andYm = maximum theoretical efficiency of microorganisms on the substrate ( $\mathrm{g}$ cells $\mathrm{g}^{-1}$ carbohydrate). We used the values recommended by Russell et al. (1992) and adopted by CNCPS: $0.4 \mathrm{~g}$ cell x g $^{-1}$ degraded carbohydrate for $\mathrm{Ym}$, and for $m$, the value of $0.05 \mathrm{~g}$ carbohydrate $\mathrm{x} \mathrm{g}^{-1}$ cell $\mathrm{x} \mathrm{h}^{-1}$.

NDF indigestible fraction was also estimated based on the protocols of Sniffen et al. (1992), being adopted as a predictive equation for the potential of NDF degradation in cattle feed by the CNCPS (Sniffen et al., 1992) and NRC (1996) (level 2 solution) systems, obtained empirically from the relationship of the residual mass of NDF after 120 days of fermentation and the lignin content in feed previously incubated (Traxler et al., 1998), described as:

$$
N D F_{i(\% N D F)}=2.4 \times L I G_{(\% N D F)}
$$

The process of evaluating the prediction equation of the indigestible fraction of the NDF of the byproducts was performed by fitting a model of linear regression between the predicted values (independent variable) and the observed values (dependent variable) in the asymptotic projection of the estimation procedure of degradation dynamics. The regression parameters were tested together on the following hypothesis by the F test: 
$H_{0}: \beta_{0}=0, \beta_{1}=1$

$H_{a}:$ no $H_{0}$

We carried out the partitioning of mean squared error of prediction (MSEP), following the protocols of Kobayashi $\&$ Salam (2000) for evaluating the prediction efficiency according to the equations:

$$
\begin{aligned}
& M S E P=S B+M a F+M o F=1 / n \sum_{i=1}^{n}\left(x_{i}+y_{i}\right)^{2} \\
& S B=(\bar{x}-\bar{y})^{2} \\
& M a F=\left(s_{x}-s_{y}\right)^{2} \\
& M o F=2 s_{x} s_{y}(1-r)
\end{aligned}
$$

where $\mathrm{x}=$ predicted values; $\mathrm{y}=$ observed values; $\mathrm{MSEP}=$ mean squared error of prediction; $\mathrm{SB}=$ squared bias; $\mathrm{MaF}=$ component relative to the magnitude of random fluctuation; $\mathrm{MoF}=$ component relative to the random fluctuation model weighted by the standard deviations; $\mathrm{s}_{\mathrm{x}}$ and $\mathrm{s}_{\mathrm{y}}=$ standard deviations for the predicted and observed values, respectively; and $\mathrm{r}=$ Pearson linear correlation between predicted and observed values.

In order to accomplish the fitting of degradation models, we used the interactive process of Marquardt algorithm, due to the high correlation between most of the degradation profiles and the variable time, the procedure used was PROC NLIN from Statistical Analysis System (SAS 9.0). The degradation model parameters were compared descriptively among the byproducts. The adjustment of the linear regression model between observed and predicted values of NDFi was performed through the PROC REG procedure (SAS 9.0), and null hypothesis was tested adopting $\alpha=0.05$.

\section{Results and Discussion}

There was a great variation in the potentially digestible and indigestible fractions of NDF among the byproducts examined (Table 2). This is due to intrinsic characteristics of the feed, mainly concerning the content of NDFpd, which ranged from $4.17 \%$ for the byproduct of the melon to $90.67 \%$ for the coconut. Considering that the fiber of basal feed (forage) is the main energy source for ruminants in the tropics (Detmann et al, 2004), it is expected that animals supplemented with these byproducts have different responses to consumption of dry matter, and consequently also in performance, since this factor is of the greatest impact on the animal response, even more than the digestibility of the diet (Poppi, 2008). Such feature is positively correlated with the protection factor that lignin exerts on NDF (Van Soest, 1994).

A wide variation was detected in degradation rates of NDFpd (Table 2), which can be considered regardless of the concentration of potentially digestible fraction, as observed in the byproduct of the West Indian cherry that despite presenting a high content of indigestible fraction $(81.61 \%)$ showed a high degradation rate of NDFpd $\left(0.0971 \mathrm{~h}^{-1}\right)$, however due to the high concentration of NDFi, the permanence time of the fiber of this byproduct in the rumen is mainly function of passage rate, which is mainly associated with the particle size and material density. In this way, measures that increase the passage rate are necessary to prevent significant rumen repletion, with lower consumption of dry matter.

Unlike the byproduct of pineapple, which presented both a high degradation rate of NDFpd $\left(0.0837 \mathrm{~h}^{-1}\right)$, and also a high potentially digestible fraction $(67.45 \%)$, which makes the disappearance of this feed fiber in the rumen a function not only of the passage to the lower digestive tract, but mainly of its digestion, thus reducing the permanence time of the feed in the rumen and favoring the increase of dry matter intake. Variations in concentrations and forms of lignin can explain differences in degradation rates of agroindustrial byproducts.

The byproducts of annatto, cashew nut and coconut presented intriguing parameters of NDF digestion, mainly

\begin{tabular}{|c|c|c|c|c|c|c|}
\hline \multirow[b]{2}{*}{ Byproducts } & \multicolumn{6}{|c|}{ Parameters } \\
\hline & $\mathrm{U}_{(\% \mathrm{NDF})}$ & $\mathrm{I}_{(\% \mathrm{NDF})}$ & $\lambda{ }_{\left(\mathrm{h}^{-1}\right)}$ & $C^{\prime}\left(h^{-1}\right)$ & $\mathrm{Up}$ & Ip \\
\hline Cashew & $29.21( \pm 1.50)$ & $72.50( \pm 1.30)$ & $0.0533( \pm 0.006)$ & 0.0318 & 0.29 & 0.71 \\
\hline Passionfruit & $41.10( \pm 2.33)$ & $61.44( \pm 1.24)$ & $0.1483( \pm 0.014)$ & 0.0884 & 0.40 & 0.60 \\
\hline Melon & $4.17( \pm 0.88)$ & $96.19( \pm 0.65)$ & $0.0761( \pm 0.033)$ & 0.0453 & 0.04 & 0.96 \\
\hline Annatto & $74.57( \pm 3.11)$ & $30.56( \pm 2.17)$ & $0.0849( \pm 0.007)$ & 0.0506 & 0.71 & 0.29 \\
\hline Pineapple & $67.45( \pm 3.79)$ & $35.15( \pm 2.07)$ & $0.1403( \pm 0.014)$ & 0.0837 & 0.66 & 0.34 \\
\hline West Indian cherry & $19.37( \pm 1.65)$ & $81.61( \pm 0.85)$ & $0.1628( \pm 0.024)$ & 0.0971 & 0.19 & 0.81 \\
\hline Cashewnut & $81.91( \pm 5.35)$ & $24.15( \pm 3.83)$ & $0.0802( \pm 0.011)$ & 0.0478 & 0.77 & 0.23 \\
\hline Grape & $14.13( \pm 1.22)$ & $86.71( \pm 1.15)$ & $0.0447( \pm 0.008)$ & 0.0267 & 0.14 & 0.86 \\
\hline Coconut & $90.67( \pm 2.93)$ & $14.10( \pm 2.00)$ & $0.0889( \pm 0.006)$ & 0.0530 & 0.87 & 0.13 \\
\hline
\end{tabular}
due to the high concentrations of NDFpd $(74.57 ; 81.91$ and $90.67 \%$, respectively). Therefore, the use of such feed for

Table 2 - Estimation of degradation parameters of agroindustrial byproducts 
animals with greatest productive merit could be feasible, emphasizing that, among these abovementioned, only cashew nut is considered a concentrate feed due to the low NDF concentration.

The almost total indigestibility of the melon, grape and West Indian cherry's byproducts fiber was associated with the composition of the studied material, mainly made up by seed coat, rich in lignin, in the case of the cashew, the low availability of NDF digestion is probably related to the high concentrations of condensed tannins observed in this byproduct (Agostini-Costa et al., 2003), which bind to cell wall compounds, resulting in indigestible complexes or complexes unavailable to bacterial enzymes.

Discrete latency was high for all byproducts (Table 3), ranging from 9.71 to $34.83 \mathrm{~h}$ for West Indian cherry and grape, respectively. The time equivalent to the point of maximum degradation rate was lower for the byproducts from the processing of West Indian cherry, pineapple and passion fruit, (Table 3 ) with respective values of $6.14 ; 6.74$ and $7.13 \mathrm{~h}$. In these we also verified the highest degradation rates of NDFpd.
Likewise, specific growth rate of microorganisms on the potentially digestible fraction (Table 3 ) was superior for the byproducts that had high degradation rates. As remarked by Costa et al. (2008), the microbial protein synthesis is closely related to the NDFpd degradation rate in diets based on low quality forage, provided that there is no shortage of nitrogen compounds.

When rumen microorganisms grow slowly, a great part of the energy of fermentation of fibrous carbohydrates is used for its maintenance, reducing the efficiency of microbial cell synthesis. This fact can be observed in the byproducts of cashew and grape (Table 3). According to Pirt (1965), bacterial maintenance is defined as a time-dependent function, and it is directly proportional to the mass of cells ( $g$ carbohydrate $\mathrm{x}^{-1}$ cell $\mathrm{x} \mathrm{h}^{-1}$ ) and maximum theoretical yield ( $\mathrm{g}$ cells x g-1 carbohydrates), defined as the yield that would be obtained if there were no maintenance (Russel et al., 1992).

Thus, feeds with high degradation rates also provide greater efficiency of microbial cells synthesis. However, using this parameter alone is unwise, because it may lead to choosing feed as the byproduct of West Indian cherry,

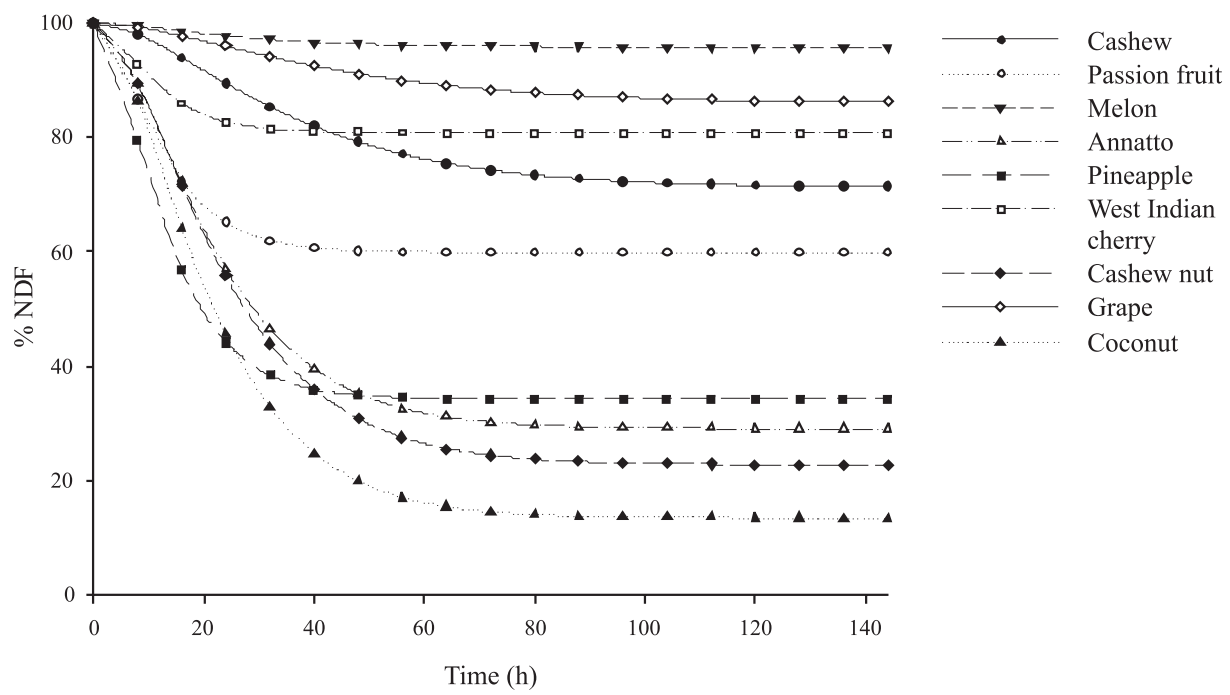

Figure 1 - Estimation of NDF degradation profiles of agroindustrial byproducts

Table 3 - Estimation of parameters of the curve of degradation and microorganisms growth on the potentially digestible fraction of neutral detergent fiber of agroindustrial byproducts

\begin{tabular}{|c|c|c|c|c|c|c|}
\hline Byproducts & $\mathrm{t}_{\mathrm{i}(\mathrm{h})}$ & $\mathrm{R}\left(\mathrm{t}_{\mathrm{i}}\right)_{(\%)}$ & $\mathrm{L}_{\text {(h) }}$ & $\mu$ & $\left.\mathrm{Sgr}_{(\mathrm{h}}{ }^{-1}\right)$ & $\mathrm{Y}_{\left(\mathrm{g} \mathrm{Mic} \times \mathrm{kg}^{-1} \mathrm{CHT}\right)}$ \\
\hline Cashew & 18.75 & 93.99 & 29.24 & 0.57 & 0.0196 & 198.13 \\
\hline Passion fruit & 6.74 & 91.68 & 10.44 & 2.25 & 0.0547 & 292.89 \\
\hline Melon & 13.16 & 99.26 & 19.54 & 0.12 & 0.0280 & 233.25 \\
\hline Pineapple & 7.13 & 84.78 & 11.48 & 3.50 & 0.0518 & 288.61 \\
\hline West Indian cherry & 6.14 & 95.85 & 9.71 & 1.16 & 0.0600 & 300.01 \\
\hline Cashew nut & 12.47 & 84.42 & 18.90 & 2.42 & 0.0296 & 238.72 \\
\hline
\end{tabular}


which despite presenting high degradation rate (Table 2) and efficiency in microbial cell growth (Table 3), would present total bacterial synthesis impaired due to lack of potentially digestible substrate.

In this way, the binomial degradation rate and concentration of potentially digestible fraction should be parameters to be evaluated together in order to choose feeds with higher nutritional value.

The effect of effective rumen degradation and rumen fill of NDF represents in an integrated manner the dynamics of NDF disappearance in rumen (Waldo et al., 1972), which are function of degradation phenomena and passage, so the probability of removal of a fibrous particle of rumen increases with the degradation rate (Costa et al., 2008). Feeds with a greater extent of degradation, as well as a high degradation rate contribute to raising levels of metabolizable energy in diets for ruminants.

Analyzing the passage rate of $0.02 \mathrm{~h}^{-1}$ (Table 4), only the byproducts of cashew nut $(11.92 \mathrm{~h})$ and coconut (21.16h) did not show total rumen fill over $24 \mathrm{~h}$. Nevertheless, these byproducts were the ones which presented highest effective degradation, 80.66 and $60.43 \%$, respectively. The byproducts from the processing of cashew, melon, West Indian cherry and grape presented total fill of over $40 \mathrm{~h}$, indicating low fiber quality. Such feeds possibly limit the dry matter intake of the farm animal, thus their use would occur only when other sources of fiber are unavailable, or for use in animal maintenance.

Parameters $\beta_{0}=2.35( \pm 11.94)$ and $\beta_{1}=1.16( \pm 0.23)$ of the regression equation between observed and predicted values of the NDFi were not different from 0 or $1(P=0.19)$, respectively (Figure 2 ). This suggests that the equation established by Sniffen et al. (1992) was sensible at predicting the NDFi values observed in the degradation experiment. This result is antagonistic to other studies under Brazilian conditions, which in assessing the factor

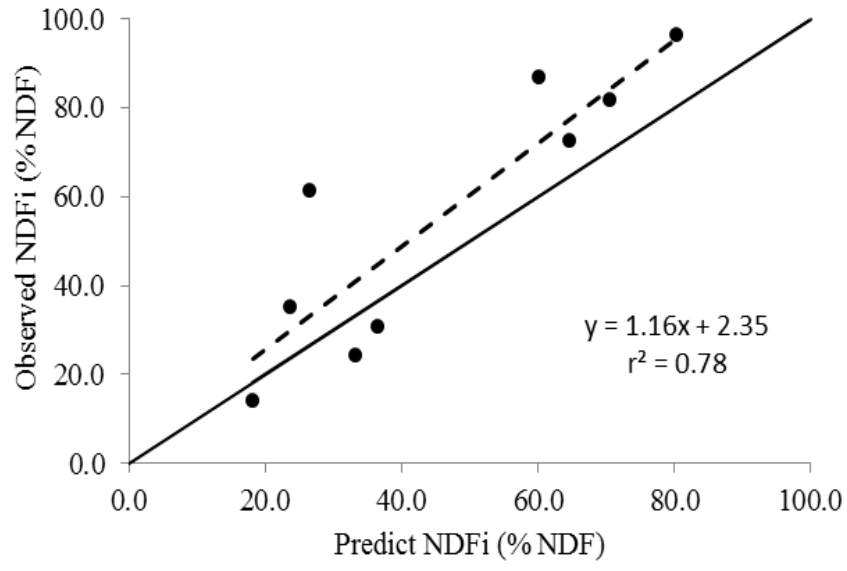

Figure 2 - Relationship between indigestible neutral detergent fiber observed and predicted by the equation of Sniffen et al. (1992) of agroindustrial byproducts

adopted by CNCPS registered bias in the results predicted (Malafaia et al., 1998; Vieira et al., 2000; Fernandes, 2001; Detmann et al., 2004).

The average ratio between lignin content (\%NDF) and indigestible fraction of NDF (\%NDF) in this study was 2.95; closer to the value adopted by CNCPS (2.4), while Malafaia et al. (1998) and Vieira et al. (2000) recorded average values of 3.03 and 4.09 .

These researchers investigated conventional feed and possibly there are differences between the ratio of lignin with carbohydrates of cell wall of these feeds and of the agroindustrial byproducts studied. However, although the equation is sensitive at predicting the values observed, the high value of the mean squared error of prediction observed (291.40) makes us understand that even among the byproducts there is a wide variation between ratio lignin and indigestible fraction. We verified relationships of 1.75 for the cashew nut, to 5.55 for the passion fruit, with coefficient of variation of $39.76 \%$.

Table 4 - Effective rumen degradation and the fill parameters of the NDF of agroindustrial byproducts

\begin{tabular}{|c|c|c|c|c|c|c|c|c|}
\hline \multirow[b]{2}{*}{$\mathrm{Kp}^{3}$} & \multicolumn{2}{|c|}{ ERD } & \multicolumn{2}{|c|}{$\mathrm{RR}_{\mathrm{U}}{ }^{\mathrm{I}}$} & \multicolumn{2}{|c|}{$\mathrm{RR}_{\mathrm{I}}^{2}$} & \multicolumn{2}{|c|}{$\mathrm{RR}_{\mathrm{T}}$} \\
\hline & 0.02 & 0.05 & 0.02 & 0.05 & 0.02 & 0.05 & 0.02 & 0.05 \\
\hline \multicolumn{9}{|l|}{ Byproducts } \\
\hline Passion fruit & 31.91 & 22.99 & 4.48 & 3.53 & 29.96 & 11.98 & 34.44 & 15.52 \\
\hline Melon & 2.61 & 1.52 & 0.78 & 0.53 & 47.92 & 19.17 & 48.70 & 19.70 \\
\hline Annatto & 48.85 & 29.54 & 12.23 & 8.57 & 14.53 & 5.81 & 26.77 & 14.38 \\
\hline Pineapple & 51.67 & 36.66 & 7.69 & 6.00 & 17.13 & 6.85 & 24.82 & 12.85 \\
\hline Grape & 6.74 & 3.15 & 3.66 & 2.18 & 42.99 & 17.20 & 46.66 & 19.38 \\
\hline Coconut & 60.43 & 37.15 & 14.43 & 10.22 & 6.73 & 2.69 & 21.16 & 12.91 \\
\hline
\end{tabular}

${ }^{1}$ Rumen fill of the potentially digestible fraction of NDF.

2 Rumen fill of the indigestible fraction of NDF.

${ }^{3}$ Passage rate. 
According to Tedeschi et al. (2000), comparisons using the root of mean squared error of prediction (RMSEP) are preferable. MSEP has been frequently used to address the model adequacy, but presents limitations as a performance indicator, since it removes negative signs and deviation weights, giving more influence to greater deviations. Moreover, when the root of MSEP is calculated, the unit becomes the same of the variables, facilitating the viewing of the error. The RMSEP observed was $17.07 \%$, showing the low likelihood of the model.

Partitioning the MSEP (Figure 3), there was greater participation in percentage $(50.31 \%)$ for the component relative to the random fluctuation model weighted by the standard deviations $(\mathrm{MoF})$. This component is related to the lack of positive correlation weighted by the standard deviations. The high value obtained for this component means that the model failed at simulating the fluctuation pattern between the measurements (Kobayashi \& Salam, 2000).

Unlike the obtained in other national studies which recorded low to moderate correlation between the lignin content and the indigestible fraction of NDF, Vieira et al. (2000), $\mathrm{r}=0.45$; Nunes et al. (2004), $\mathrm{r}=0.12$ and Detmann et al. (2004), $r=0.68$, the correlation obtained in this experiment was high and significant $(\mathrm{r}=+0.88 ; \mathrm{P}<0.01)$. However, due to the small size of database used here $(n=9)$, more reliable assessments about the relationship between lignin and indigestible fraction of NDF of agroindustrial byproducts become impossible.

As pointed out by Vieira et al. (2000) and Detmann et al. (2007), simple gravity estimates would not accurately estimate the real inhibitory effect of lignin on the fibrous carbohydrate of feeds. In this way, such measurement should be done through direct biological methods as in situ or in vitro degradations, which could be incorporated into the laboratory routine, thus decreasing the bias of these estimates.

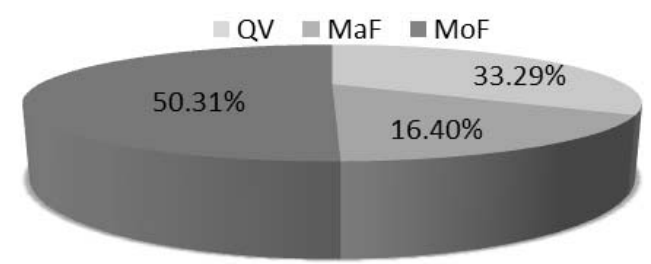

Figure 3 - Partitioning of the mean squared error of prediction of the indigestible neutral detergent fiber of agroindustrial byproducts.

\section{Conclusions}

Agroindustrial byproducts present great variation in the parameters of ruminal degradation of neutral detergent fiber. The use of such feeds in ruminant diets should be based on levels of expected productivity and availability. The estimation of digestible or indigestible fraction of neutral detergent fiber of agroindustrial byproducts through biological methods must be preferably used rather than that obtained by the prediction equation adopted by Cornell Net Carbohydrate and Protein System, thus preventing bias in the results and enabling more accurate assessments of the nutritional value of these feeds.

\section{References}

AGOSTINI-COSTA, T.S.; LIMA, A.; LIMA, M.V. Determinação de tanino em pedúnculo de caju: método da vanilina versus método do butanol ácido. Química Nova, v.26, n.5, p.763-765, 2003. ASSOCIATION OF OFFICIAL ANALYTICAL CHEMISTS - AOAC. Official methods of analysis. 15.ed. Virginia: Arlington, 1990. $1117 \mathrm{p}$.

BEUVINK, J.M.W.; KOGUT, J. Modeling gas production kinetics of grass silages incubated in ruminal fluid. Journal of Animal Science, v.71, n.4, p.1041-1046, 1993.

BROCK, T.D.; MADIGAN, M.T.; MARTINKO, J.M. et al. Biology of Microorganisms. 7.ed. Englewood Cliffs: Prentice-Hall International, 1994. 909p.

CABRAL, L.S.; VALADARES FILHO, S.C.; ZERVOUDAKIS, J.T.; et al. Degradabilidade in situ da matéria seca, da proteína bruta e da fibra de alguns alimentos. Pesquisa Agropecuária Brasileira, v.40, n. 8, p.777-781, 2005.

COSTA, V.A.C.; DETMANN, E.; VALADARES FILHO, S.C. et al. Degradação in vitroda fibra em detergente neutro de forragem tropical de baixa qualidade em função de suplementação com proteína e/ou carboidratos. Revista Brasileira de Zootecnia, v.37, n.3, p.494-503, 2008.

DETMANN, E.; COELHO DA SILVA, J.F.; VÁSQUEZ, H.M. et al. Cinética da degradação ruminal dos carboidratos de quatro gramíneas tropicais em diferentes idades de corte e doses de adubação nitrogenada: Técnica de produção de gases. Revista Brasileira de Zootecnia, v.38, n.1, p.149-158, 2009.

DETMANN, E.; VALADARES FILHO, S.C.; HENRIQUES, L.T. et al. Reparametrização do modelo baseado na lei de superfície para predição da fração digestível da fibra em detergente neutro em condições brasileiras. Revista Brasileira de Zootecnia, v.36, n.1, p.155-164, 2007.

DETMANN, E.; ZERVOUDAKIS, J.T.; CABRAL, L.S. et al. Validação de equações preditivas da fração indigestível da fibra em detergente neutro em gramíneas tropicais. Revista Brasileira de Zootecnia, v.33, n.6, p.1866-1875, 2004 (supl. 1).

ELLIS, W.C.; MATIS, J.H.; HILL, T.M. et al. Methodology for estimating digestion and passage kinetics of forages. In: FAHEY JR., G.C. (Ed.) Forage quality, evaluation and utilization. Madison: American SocietyofAgronomy, 1994. p.682-756.

FERNANDES, A.M. Valor nutritivo da cana-de-açúcar (Sacharumspp.) em função dos ciclos de produção precoce e intermediário e da idade de corte. 2001. 81f. Tese (Doutorado em Zootecnia) - Universidade Federal de Viçosa, Viçosa, MG.

KOBAYASHI, K.; SALAM, M.U. Comparing simulated and measured values using mean squared deviation and its components. Agronomy Journal, v.92, n.2, p.345-352, 2000. 
LICITRA, G.; HERNANDES, T.M.; Van SOEST, P.J. Standardization of procedures for nitrogen fractionation of ruminants feeds. Animal Feed Science and Technology, v.57, p.347-358, 1996.

MALAFAIA, P.A.M.; VALADARES FILHO, S.C.; VIEIRA, R.A.M. et al. Determinação das frações que constituem os carboidratos totais e da cinética ruminal da fibra em detergente neutro de alguns alimentos para ruminantes. Revista Brasileira de Zootecnia, v.27, n.4, p.790-796, 1998.

MERTENS, D.R. Gravimetric determination of amylase-treated neutral detergent fibre in feeds with refluxing beakers or crucibles: collaborative study. Journal of AOAC International, v.85, p.1217-1240, 2002.

NATIONAL RESEARCH COUNCIL - NRC. Nutrient requirements of beef cattle. 7.ed. Washington, D.C.: 1996. 242p.

NUNES, L.B.M.; DETMANN, E.; COELHO DA SILVA, J.F. et al. Correlações lineares parciais entre componentes da parede celular em gramíneas tropicais cultivadas na Região Norte Fluminense. In: ENCONTRO DE INICIAÇÃO CIENTÍFICA, 9., 2004, Campos dos Goytacazes. Anais... Campos dos Goytacazes: Universidade Estadual do Norte Fluminense, 2004. (CD-ROM).

ØRSKOV, E.R.; McDONALD, I. The estimation of protein degradability in the rumen from incubation measurements of feed in weighted according to rate passage. Journal of Agricultural Science, v.92, n.2, p.499-503, 1979.

PIRT, S.J. The maintenance energy of bacteria in growing cultures. Proceedings of Royal Society, Series B, v.163, p.224-231, 1965.

POPPI, D.P. The dilemma in models of intake regulation: mechanistic or empirical. In: FRANCE, J; KEBREAB, E. (Eds.) Mathematical modelling in animal nutrition. Wallingford: CAB International, 2008. p.121-141.
RUSSELL, J.B.; O'CONNOR, J.D.; FOX D.G. et al. A net carbohydrate and protein system for evaluating cattle diets: I. Ruminal fermentation. Journal of Animal Science, v.70, n.11, p.3551-3561, 1992 .

SNIFFEN, C.J.; O'CONNOR, D.J.; VAN SOEST, P.J. et al. A net carbohydrate and protein system for evaluating cattle diets: carbohydrate and protein availability. Journal of Animal Science, v.70, n.11, p.3562-3577, 1992.

TEDESCHI, L.O.; FOX, D.G; RUSSEL, J.B. Accounting for the effects of a ruminal nitrogen deficiency within the structure of the Cornell Net Carbohydrate and Protein System. Journal of Animal Science. v.78, n.6, p.1648-1658, 2000

TRAXLER, M.J.; FOX, D.G.; VAN SOEST, P.J. et al. Predicting forage indigestible NDF from lignin concentration. Journal of Animal Science, v.76, n.5, p.1469-1480, 1998.

VAN MILGEN, J.; MURPHY, L.L.; BERGER, L.L. A compartmental model to analyze ruminal digestion. Journal of Dairy Science, v.74, n.8, p.2515-2529, 1991.

VAN SOEST, P.J. Nutritional ecology of the ruminant. 2.ed. Ithaca: Cornell University Press, 1994. 476p.

VIEIRA, R.A.M.; PEREIRA, J.C.; MALAFAIA, P.A.M. et al Fracionamento dos carboidratos e cinética de degradação in vitroda fibra em detergente neutro da extrusa de bovinos a pasto. Revista Brasileira de Zootecnia, v.29, n.3, p.889-897, 2000.

VIEIRA, R.A.M.; PEREIRA, J.C.; MALAFAIA, P.A.M. et al. The influence of elephant-grass (Pennisetumpurpurem Schum. Mineiro variety) growth on the nutrient kinetics in the rumen. Animal Feed Science and Technology, v.67, n.2-3, p.151-161, 1997.

WALDO, D.R.; SMITH, L.W.; COX, E.L. Model of cellulose disappearance from the rumen. Journal of Dairy Science, v. 55, n. 1, p. $125-129,1972$ 